\title{
EPIDEMIOLOGICAL AND ETIOLOGICAL ASPECTS OF ENTEROVIRUS INFECTION IN RUSSIA AND VIETNAM
}

\author{
N.I. Romanenkova ${ }^{a}$, L.N. Golitsyna ${ }^{b}$, T.T.T. Nguyen ${ }^{c}$, N.V. Ponomareva ${ }^{b}$, A.V. Leonov ${ }^{b}$, \\ O.I. Kanaeva ${ }^{a}$, V.V. Zverev ${ }^{b}$, S.G. Selivanova ${ }^{b}$, N.R. Rozaeva ${ }^{a}$, M.T. Luong ${ }^{d}$, \\ M.A. Bichurina ${ }^{a}$, N.A. Novikova ${ }^{b}$ \\ a St. Petersburg Pasteur Institute, St. Petersburg, Russian Federation \\ ${ }^{b}$ Blokhina Scientific Research Institute of Epidemiology and Microbiology of Nizhny Novgorod, Nizhny Novgorod, \\ Russian Federation \\ ' Institut Pasteur in Ho Chi Minh City, Ho Chi Minh City, Vietnam \\ ${ }^{d}$ Russian-Vietnamese Tropical Research and Technology Center, South Branch, Ho Chi Minh City, Vietnam
}

\begin{abstract}
The epidemic situation and etiological factors of enterovirus infection in Russia and Vietnam were analysed and compared. The identified strains of enteroviruses of 47 types, which circulated in Russia in 2018-2019, belonged to different species: Enterovirus species A (CV-A2, CV-A4, CV-A6, CV-A8, CV-A10, CV-A16, EV-A71), as well as Enterovirus species B and Enterovirus species C. The strains isolated from 87 children from southern Vietnam hospitalised in 2018-2019 into infectious hospitals while having enterovirus infection with exanthema were also studied. All identified strains were represented by Enterovirus species A: EV-A71 - 59 strains, CV-A10 - 20 strains, CV-A16 5 strains, CV-A6 - two strains and CV-A2 - one strain. Out of 59 viruses EV-A71, 53 strains belonged to genotype C4 and 6 strains belonged to genotype B5. The sequences of EV-A71 strains of genotype C4 from South Vietnam formed a monophyletic cluster with the sequences of EV-A71 viruses which circulated during 2016-2018 in different provinces of China, and they were very close to EV-A71 strains of the same genotype from the Yunnan Province. These strains were genetically different from Russian viruses and Vietnamese viruses identified in the years 2003-2005 and 20112012. Most of the cases of enterovirus infection from southern Vietnam (78\%) caused by EV-A71 virus of genotype C4 were reported in three provinces located in southern Vietnam in the Mekong Delta. The epidemic process and the etiology of enterovirus infection in Russia and Vietnam have common features. At the same time, the epidemic situation in these countries is not the same. The incidence of enterovirus infection is influenced by geographic, climatic, economic and demographic factors that differ in two countries. In the majority of territories of Russia, the climate is temperate or cold, seasonal rises in the incidence rates of enterovirus infection usually occur in the summer, when people go on vacation, spend a lot of time outdoors and swim in open reservoirs. In Vietnam, a constant high-level temperature, a high population density and a large proportion of children determine the higher incidence of enterovirus infection, especially in the southern provinces of Vietnam, compared to Russia. The fact that more than $20 \%$ of the Vietnamese population lives in the Mekong Delta, which is the largest river in Indochina, has a significant impact on the epidemic process of enterovirus infection in South Vietnam. The Mekong River which flows through China, Laos, Thailand, Cambodia and Vietnam, and carries huge streams of water, including rainstorm waters and sewages, from all of these
\end{abstract}

\author{
Адрес для переписки: \\ Романенкова Наталья Ивановна \\ 197101, Россия, Санкт-Петербург, ул. Мира, 14, \\ ФБУН НИИ эпидемиологии и микробиологии имени Пастера. \\ Тел.: 8 (812) 233-21-56. Факс: 8 (812) 232-92-17. \\ E-mail: romanenkova@pasteurorg.ru
}

\author{
Contacts: \\ Natalya I. Romanenkova \\ 197101, Russian Federation, St. Petersburg, Mira str., 14, \\ St. Petersburg Pasteur Institute. \\ Phone: +7 (812) 233-21-56. Fax: +7 (812) 232-92-17 \\ E-mail: romanenkova@pasteurorg.ru
}

\section{Citation:}

Romanenkova N.I., Golitsyna L.N., Nguyen T.T.T., Ponomareva N.V., Leonov A.V., Kanaeva O.I., Zverev V.V., Selivanova S.G., Rozaeva N.R., Luong M.T., Bichurina M.A., Novikova N.A. Epidemiological and etiological aspects of enterovirus infection in Russia and Vietnam // Russian Journal of Infection and Immunity = Infektsiya i immunitet, 2021, vol. 11, no. 5, pp. 905-916. doi: 10.15789/2220-7619-EAE-1791
Для цитирования:
Романенкова Н.И., Голицына Л.Н., Нгуен Т.Т.Т., Пономарева Н.В., Леонов А.В., Канаева О.И., Зверев В.В., Селиванова С.Г., Розаева Н.Р., Лыонг М.Т., Бичурина М.А., Новикова Н.А. Эпидемиологические и этиологические аспекты энтеровирусной инфекции в России и Вьетнаме // Инфекция и иммунитет. 2021. Т. 11, № 5. С. 905-916. doi: 10.15789/2220-7619-EAE-1791 
countries into the southern provinces of Vietnam, which have the highest incidence rates of enterovirus infection in the country. The results of the research underline the importance of active epidemiological and virological surveillance of enterovirus infection, which plays the key role in informing the public health authorities about the changes in the epidemic situation in order to take appropriate measures and develop the prevention strategies. The goal of anti-epidemic and preventive measures is to reduce the incidence of enterovirus infection and the economic burden of this infection for Russia and Vietnam.

Key words: enterovirus infection, epidemic process, circulation, identification.

\section{ЭПИДЕМИОЛОГИЧЕСКИЕ И ЭТИОЛОГИЧЕСКИЕ АСПЕКТЫ ЭНТЕРОВИРУСНОЙ ИНФЕКЦИИ В РОССИИ И ВЬЕТНАМЕ}

Романенкова Н.И. ${ }^{1}$, Голицына Л.Н. ${ }^{2}$, Нгуен Т.Т.Т. ${ }^{3}$, Пономарева Н.В. ${ }^{2}$, Леонов А.В. ${ }^{2}$, Канаева О.И. $^{1}$, Зверев В.В. ${ }^{2}$, Селиванова С.Г. ${ }^{2}$, Розаева Н.Р. ${ }^{1}$, Лыонг М.Т. ${ }^{4}$, Бичурина М.А. ${ }^{1}$, Новикова Н.А. ${ }^{2}$

${ }^{\prime}$ ФБУН НИИ эпидемиологии и микробиологии имени Пастера, Санкт-Петербург, Россия

${ }^{2}$ ФБУН Нижегородский НИИ эпидемиологии и микробиологии им. академика И.Н. Блохиной, Нижний Новгород, Россия

${ }^{3}$ Институт Пастера в Хошимине, г. Хошимин, Вьетнам

${ }^{4}$ Российско-Вьетнамский тропический научно-исследовательский и технологический центр, южное отделение,

2. Хошимин, Вьетнам

Резюме. Проведены анализ и сравнение эпидемической ситуации и этиологии энтеровирусной инфекции в России и во Вьетнаме. Идентифицированные штаммы энтеровирусов 47 типов, которые циркулировали в России в 2018-2019 гг., относились к разным видам: виду Энтеровирус A (CV-A2, CV-A4, CV-A6, CV-A8, CV-A10, CV-A16, EV-A71), виду Энтеровирус В и виду Энтеровирус С. Также были изучены штаммы энтеровирусов, изолированные от 87 детей из южного Вьетнама, госпитализированных в 2018-2019 гг. в инфекционные стационары с экзантемными формами энтеровирусной инфекции. Все эти штаммы принадлежали к виду Энтеровирус А, было идентифицировано 59 штаммов EV-A71, 20 штаммов CV-A10, 5 штаммов CV-A16, два штамма CV-A6 и один штамм CV-A2. Из 59 вирусов EV-A71 53 штамма относились к генотипу C4 и 6 штаммов - к генотипу B5. Последовательности штаммов EV-A71 генотипа C4 из Южного Вьетнама сформировали монофилетический кластер с последовательностями вирусов EV-A71 генотипа C4, циркулировавшими в 2016-2018 гг. в разных провинциях Китая, особенно близки они были к штаммам того же генотипа из провинции Юньнань. Эти штаммы генетически отличались как от российских вирусов, так и от вьетнамских вирусов, идентифицированных в 2003-2005 и 2011-2012 гг. Большинство изученных случаев энтеровирусной инфекции из южного Вьетнама (78\%), вызванных EV-A71 генотипа C4, было зарегистрировано в трех провинциях, расположенных на юге Вьетнама в дельте Меконга. Течение эпидемического процесса и этиология энтеровирусной инфекции в России и во Вьетнаме имеют много общего. В то же время эпидемическая ситуация в двух странах неодинаковая. На заболеваемость инфекцией влияют географические, климатические, экономические и демографические факторы, которые различаются в этих странах. На большей части территорий России климат умеренный или холодный, сезонные подъемы заболеваемости, как правило, происходят летом, в сезон отпусков, когда население активно перемещается, люди проводят много времени на свежем воздухе и купаются в открытых водоемах. Во Вьетнаме постоянный высокий температурный фон, высокая плотность населения, большой удельный вес детей обусловливают высокие показатели заболеваемости энтеровирусной инфекцией, особенно в южных провинциях. Более $20 \%$ населения Южного Вьетнама проживает в дельте реки Меконг, которая является крупнейшей рекой Индокитая и протекает по территории Китая, Лаоса, Таиланда, Камбоджи и Вьетнама, что оказывает существенное влияние на эпидемический процесс энтеровирусной инфекции. Река проносит огромные потоки воды, включая ливневые и сточные воды, из всех этих стран в южные провинции Вьетнама, где отмечаются самые высокие показатели заболеваемости в стране. Полученные результаты подчеркивают значение активного эпидемиологического и вирусологического надзора за энтеровирусной инфекцией, который играет ключевую роль в информировании управленческих структур здравоохранения о развитии эпидемической ситуации для принятия адекватных мер и разработки стратегии профилактики этой инфекции. Целью противоэпидемических и профилактических мероприятий является снижение заболеваемости энтеровирусной инфекцией и экономического ущерба, который наносит эта инфекция России и Вьетнаму.

Ключевые слова: энтеровирусная инфекция, эпидемический процесс, ииркуляция, идентификация. 


\section{Introduction}

Enterovirus infection is characterized by a wide diversity of clinical forms. The most severe forms of infection include enterovirus meningitis, meningoencephalitis and acute flaccid paralysis. Epidemic rises of enterovirus meningitis, caused by enteroviruses of different types such as ECHO 6, 9, 30 and Coxsackievirus B1-6, were periodically recorded in the Russian Federation, including the NorthWest of Russia [1, 5, 9, 13, 14, 17]. At the same time, in Russia a trend towards an increase in the proportion of enterovirus infection with exanthema $[2,3$, $4,6,15,16]$ has been fixed in recent years. The etiological factors of enterovirus infection with exanthema are most often enteroviruses, which belong to species A: EV-A71, Coxsackieviruses A6, A10 and A16 [2, 3, 4, 6, 15, 16, 19, 23].

Certain types of enteroviruses can dominate in the circulation among the population for several years, then can disappear and then emerge some years later. It should be noted that the observed changes in the structure of clinical forms of enterovirus infection are coherent with the process of changing the types and genotypes of enteroviruses prevailing in the circulation among the population. At the beginning of the $21^{\text {st }}$ century, on most territories, epidemic peaks of EVI were associated with the active circulation of enteroviruses of type B, which caused diseases of enterovirus meningitis. In recent years, more active circulation of enteroviruses of type A has been observed on the territories of Russia.

In South-East Asia, the most common form of enterovirus infection is the viral exanthema of mouth and extremities (Hand, Foot and Mouth Disease HFMD). This disease is usually mild, characterized by fever, malaise, rash on the hands and legs, rash and ulcerations of the oral mucosa. The infection can be complicated by pathology of the nervous or cardiovascular systems. Complications can lead to cognitive and motor disorders, meningitis and cordial troubles. Infection can be fatal due to pulmonary oedema or encephalitis [29, 30, 33, 39]. Lethality ranges from $0.5 \%$ to $19 \%$ [29] depending on the genotype of virus [37]. For example, in 2014, about 2.7 million cases of the disease were registered in China and 384 people died [39]. The severe clinical forms of infection and complications are connected mainly with the virus EV-A71 which can cause outbreaks and sporadic cases of HFMD [19, 38].

The first cases of HFMD complicated by encephalitis were reported in Vietnam in 2003 during an outbreak of acute encephalitis in Ho Chi Minh City, when Enterovirus EV-A71 was for the first time isolated from children by the researchers of Pasteur Institute in Ho Chi Minh City. The results of the first epidemiological and virological study of HFMD were published later [36]. In 2005, 764 children admitted to the children's hospital in Ho Chi Minh City with symptoms of HFMD were examined by virological method. In $54 \%$ of cases, enteroviruses were detected, $42 \%$ of them were EV71, and 52\% were CVA16. In 51 patients (29\%) with infection associated with EV71, the disease was accompanied by severe neurological complications, and three cases were fatal [36].

The peculiarities of the circulation of various types and genotypes of enteroviruses and the mechanisms of change of dominating in the circulation types are not very clear [1, 15, 22]. According to the scientific data, non-poliomyelitis enteroviruses can cause sporadic cases and outbreaks of infection [28, 41]. These facts emphasize the importance of epidemiological and virological surveillance of enterovirus infection $[15,16,28,41]$ as well as of the scientific analysis of this problem.

The aim of our research was to analyze and compare the epidemic situation and etiological factors of enterovirus infection in Russia and Vietnam.

\section{Materials and methods}

The scientific research was accomplished within the framework of scientific and technical cooperation between research institutes of the Russian Federation and Vietnam. The strains of non-polio enteroviruses isolated from 87 patients having HFMD from South Vietnam in 2018-2019 were studied. Isolation of the strains from biological material was carried out on cell cultures RD (CDC, RIVM/ WHO) and Hep2 (Cincinnati, RIVM/WHO) using standard procedures recommended by the World Health Organization [40] in the virology laboratory of the Pasteur Institute in Ho Chi Minh City. The type of enterovirus was determined in Blokhina Research Institute of epidemiology and microbiology in Nizhny Novgorod by modified partial sequencing the VP1 genome region [12, 32], the amplification of cDNA of full sequence of VP1 region of EVA71 was performed in automatic mode on a Genome $\mathrm{Lab}^{\mathrm{TM}} \mathrm{GeXP}$ genetic analyzer. Alignment of nucleotide sequences, construction of phylogenic trees, and analysis of phylogenetic relationships were performed using the software MEGA 7.0 [26]. The epidemiological and statistical analysis was performed in Pasteur Institute in St. Petersburg. The average errors were determined, and the significance of statistical differences between certain indices was evaluated using the Student's t-test. Differences were considered statistically significant at $95 \%$ confidence interval (values of $\mathrm{p}<0.05$ ).

\section{Results}

Biological material from children with HFMD was collected in the southern provinces of Vietnam. In accordance with the recommendations of the World Health Organization, 87 non-poliomyelitis enteroviruses which belonged to species A of enterovi- 
ruses were isolated from patients with the help of cell cultures RD and Hep2. The strains were studied and characterized using molecular methods. The majority of isolated enteroviruses were represented by type EV-A71 (67.8\%), 23\% of viruses were identified as CV-A10, 5.8\% - as CV-A16, 2.3\% - as CV-A6 and $1.1 \%$ - as CV-A2. According to molecular analysis 53 from 59 strains of EV-A71 belonged to the genotype $\mathrm{C} 4$, only 6 strains of EV-A71 strains were represented by the genotype B5.

We carried out the clinical and epidemiological analysis of 59 cases of enterovirus infection, the etiological factor of which was enterovirus EV-A71. All the cases of enterovirus infection were registered in the southern provinces of Vietnam in 2018-2019. The cases of infection were revealed in 12 provinces. Among 59 cases 46 cases were registered in three provinces: Dong Thap, An Giang and Ben Tre, in other 9 provinces from one to three cases of infection were reported. It is important to note that $40.7 \%$ of all cases were recorded in the province of Dong Thap located in the southwestern part of Vietnam on the border with the Kingdom of Cambodia. Two neighboring provinces Dong Thap and An Giang represent a single epidemiological focus. In the province of Ben Tre $20 \%$ of studied cases of enterovirus infection were detected. These three provinces situated in the delta of Mekong - the greatest river of Indochina accumulated $78 \%$ of all cases of HFMD included in this research.

Clinically, all the cases were classified as HFMD. The distribution of HFMD cases by the severity of the disease and the epidemiological data are represented in the table below (Table).

Among 59 cases of HFMD 6 patients had a mild form of the disease - grade I. The disease was characterized by papulovesicular rash on the skin of the hands and or feet, as well as vesicles and ulcerations on the oral mucosa, and was accompanied by sub febrile temperature. Most part of the diseases (76.3\%) were of moderate severity - grade II. In addition to exanthema of the skin, the hands, the feet and enanthema of the oral mucosa, these patients had high fever, as well as neurological and cardiovascular complications, such as muscle cramps, confusion, meningitis and myocarditis of moderate severity. Maximum severity of the disease - grade III was noted in 8 pa- tients (13.5\%). Diseases with a typical rash on the body and mouth, as well as high and prolonged fever, were accompanied by severe complications involving the nervous, cardiovascular and respiratory systems. Severe manifestations of meningitis, encephalitis, endocarditis, myocarditis, pericarditis, as well as paralytic manifestations were recorded. One child (aged 19 months) had the most severe complications of the infection which led to cognitive disorders, cordial and pulmonary troubles, the disease was fatal due to toxic shock and pulmonary oedema. The total percentage of moderate and severe forms of infection characterized by complications from various organs and systems among the analyzed HFMD cases was $89.8 \%$ and significantly exceeded $(\mathrm{p} \leq 0.001)$ the percentage of mild clinical forms of this disease.

The majority of patients suffering from HFMD $(83 \%)$ were children under the age of three years, mainly children of age between one and two years. The number of cases among children from 3 to 6 years old amounted to $17 \%$. The proportion of children under three years of age among the total number of sick children significantly exceeded $(p \leq 0.001)$ the percentage of children from three to six years. Among the patients, there were more boys $(64.4 \%)$ than girls (35.6\%). The proportion of boys among patients with HFMD significantly exceeded $(\mathrm{p} \leq 0.05)$ the same indicator for the girls with the same infection.

According to the State Report of the Russian Federation, the incidence rate of EVI was 9.83 and 12.63 per 100,000 of population in 2018 and 2019 correspondingly $[10,11]$. The highest incidence was observed among children under 17 years of age $(92.6 \%$ in 2018 and $91.89 \%$ in 2019). During these two years on some territories where a share of enterovirus meningitis was low children from 1 to 2 years old were mostly affected by other clinical forms of enterovirus infection, children from 3 to 14 years old more often suffered from enterovirus meningitis [5]. The results of studies, carried out in Russia in 2018-2019 using molecular methods showed that 2,836 enterovirus strains belonging to 47 types were identified. Those were the viruses of four species - Enterovirus species A: CV-A2, CV-A4-CV-A8, CV-A10, CV-A16, EV-A71, EV-A89; Enterovirus species B: CV-A9, CV-B1-CV-B5, E2-E7, E9, E11, E13-E16, E18E21, E25, E30, E31, E33, EV-B81; Enterovirus spe-

Table. Clinical and epidemiological characteristics of HFMD cases

\begin{tabular}{|l|c|c|c|c|c|c|c|}
\hline \multirow{2}{*}{ Year } & \multicolumn{6}{|c|}{ Cases of HFMD caused by the enteroviruses EV-A71 } \\
\cline { 2 - 8 } & \multirow{2}{*}{$\begin{array}{c}\text { Number } \\
\text { of patients }\end{array}$} & \multicolumn{2}{|c|}{ Severity grade } & \multicolumn{2}{|c|}{ Sex } & \multicolumn{3}{c|}{ Age group } \\
\cline { 2 - 8 } & $\begin{array}{c}\text { Grade I } \\
\% \mathbf{M}\end{array}$ & $\begin{array}{c}\text { Grade II + III } \\
\% \mathbf{M} \pm \mathbf{m}\end{array}$ & $\begin{array}{c}\text { Boys } \\
\% \mathbf{M} \pm \mathbf{m}\end{array}$ & $\begin{array}{c}\text { Girls } \\
\% \mathbf{M} \pm \mathbf{m}\end{array}$ & $\begin{array}{c}\text { Under } \\
\mathbf{3} \text { years } \\
\% \mathbf{M} \pm \mathbf{m}\end{array}$ & $\begin{array}{c}\mathbf{3}-\mathbf{6} \text { years } \\
\% \mathbf{M} \pm \mathbf{m}\end{array}$ \\
\hline $\mathbf{2 0 1 8}$ & 45 & 0 & 41 & 26 & 19 & 37 & 8 \\
\hline $\mathbf{2 0 1 9}$ & 14 & 6 & 8 & 12 & 2 & 12 & 2 \\
\hline Total 2018-2019 & 59 & 6 & 53 & 38 & 21 & 49 & 10 \\
$10,2 \pm 3,9$ & $89,8 \pm 3,9$ & $64,4 \pm 6,2$ & $35,6 \pm 6,2$ & $83,0 \pm 4,9$ & $17,0 \pm 4,9$ \\
\hline
\end{tabular}




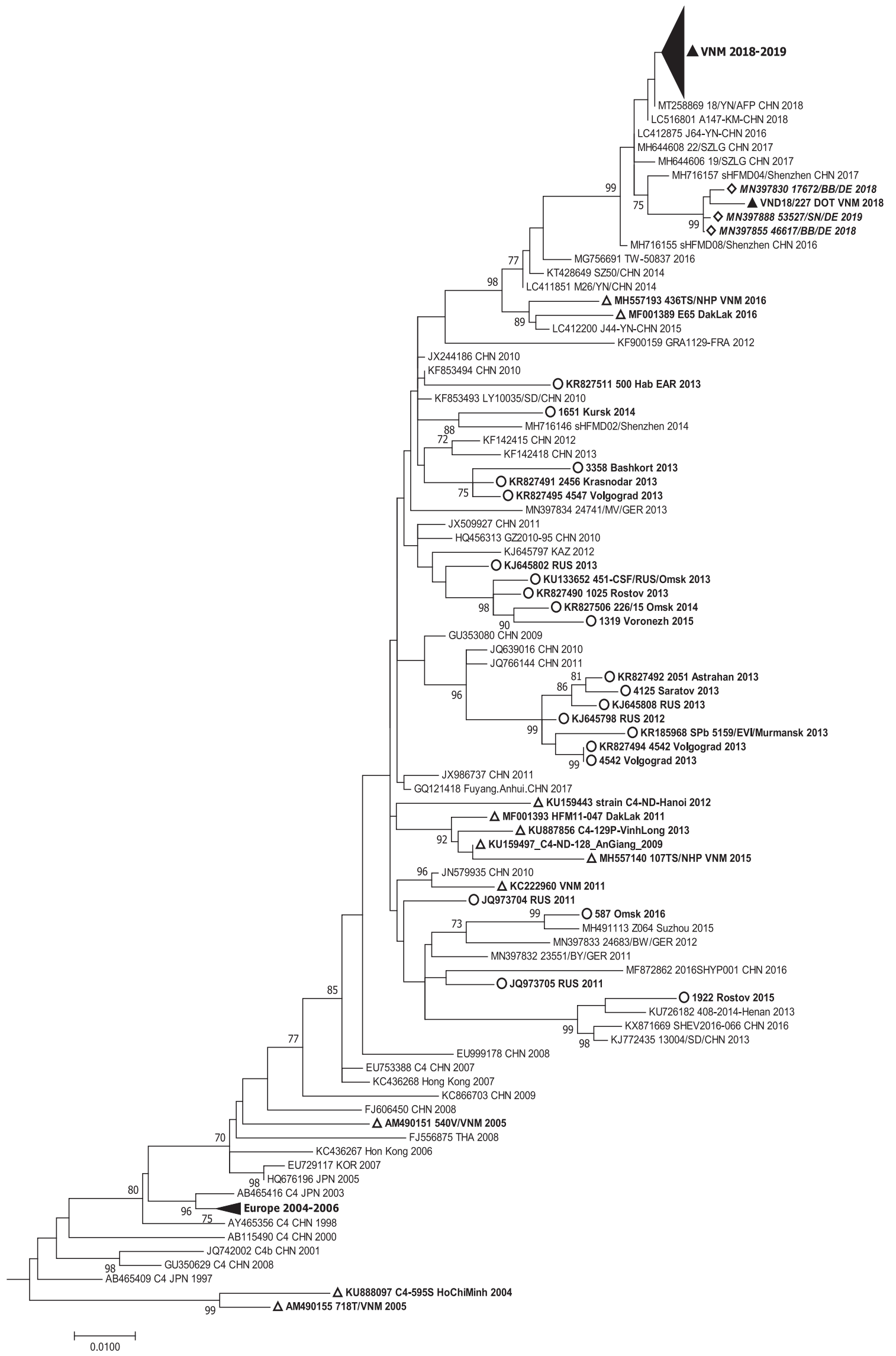

Figure 1. Phylogenic relationship between EV-A71 strains of genotype C4 identified in Russia and Vietnam Note: $\bigcirc-$ Russian strains, $\mathbf{\Delta}-$ Vietnamese strains described in this study, $\triangle-$ Vietnamese strains described in other studies, $\diamond-$ strains identified in Germany. 
cies C: CV-A1, CV-A19, CV-A20, CV-A21, CV-A22, CV-A24, EV-C96, EV-C99, EV-C116; Enterovirus species D: EV-D68 [5, 7]. The ratio of viruses of EVA:EVB:EVC species was 45.61\%:53.06\%:1.25\% in 2018 and 59.49\%:36.60\%:3.91\% in 2019. The leading etiological agents of enterovirus meningitis in 2018-2019 were viruses E6, E9, E30 and CV-B5. The viruses of species Enterovirus A were mainly detected in patients having EVI with exanthema. The virus CV-A6 dominated, its proportion in the structure of the etiological agents of EVI in these years averaged $21.47 \%$; the CV-A16 virus was also detected quite often (12.34\%). The proportion of EVA71 among all identified viruses was 4.30\% (122 strains). All of the strains of virus EV-A71 belonged to the genotype $\mathrm{C} 1$; they showed a genetic relationship with the viruses of this genotype circulating during the same period in Europe [20].

We defined that 53 EV-A71 strains from 59 studied strains, isolated in South Vietnam, belonged to genotype $\mathrm{C} 4$, six strains represented the B5 genotype. The obtained full nucleotide sequences of VP1 genome region of $59 \mathrm{EV}-\mathrm{A} 71$ strains were submitted in the International GenBank, they are available under the numbers MW139687-MW139744.

Then a phylogenic analysis of the nucleotide sequences of VP1 genome region of studied Vietnamese EV-A71strains of the genotype $\mathrm{C} 4$ and the sequences of Russian viruses of the same genotype identified earlier [4, 18] was carried out (Fig. 1).

The sequences of the strains collected in the provinces of South Vietnam formed a monophyletic cluster with the nucleotide sequences of EV-A71 viruses circulating in some provinces of China during 2016-2018 and in Germany during 2018-2019 [20, $35]$. The highest homology (99.2-99.9\%) of the nucleotide sequences of majority of Vietnamese strains belonging to this genetic group was revealed with the strains identified in patients with HFMD and AFP from the Chinese province of Yunnan in 20172018. The strain VND18/227, isolated in 2018 from a patient with clinical severity IIB from Dong Thap province, showed the greatest genetic relationship (99.2-99.4\% of homology) with the strains EV-A71 of genotype C4 isolated in Germany. These strains formed together a separate genetic group and were mostly close to viruses EV-A71 which circulated in the Chinese province of Guangdong in 2017. The studied Vietnamese strains EV-A71 of genotype C4 genetically differed from Russian viruses as well as from viruses identified in South Vietnam [30] during HFMD outbreaks of 2003-2005 and 2011-2012 and in North Vietnam [21] and Dak Lak Province [27] in 2016.

The sequences of studied EV-A71 strains of genotype B5 formed a monophyletic group (Fig. 2).

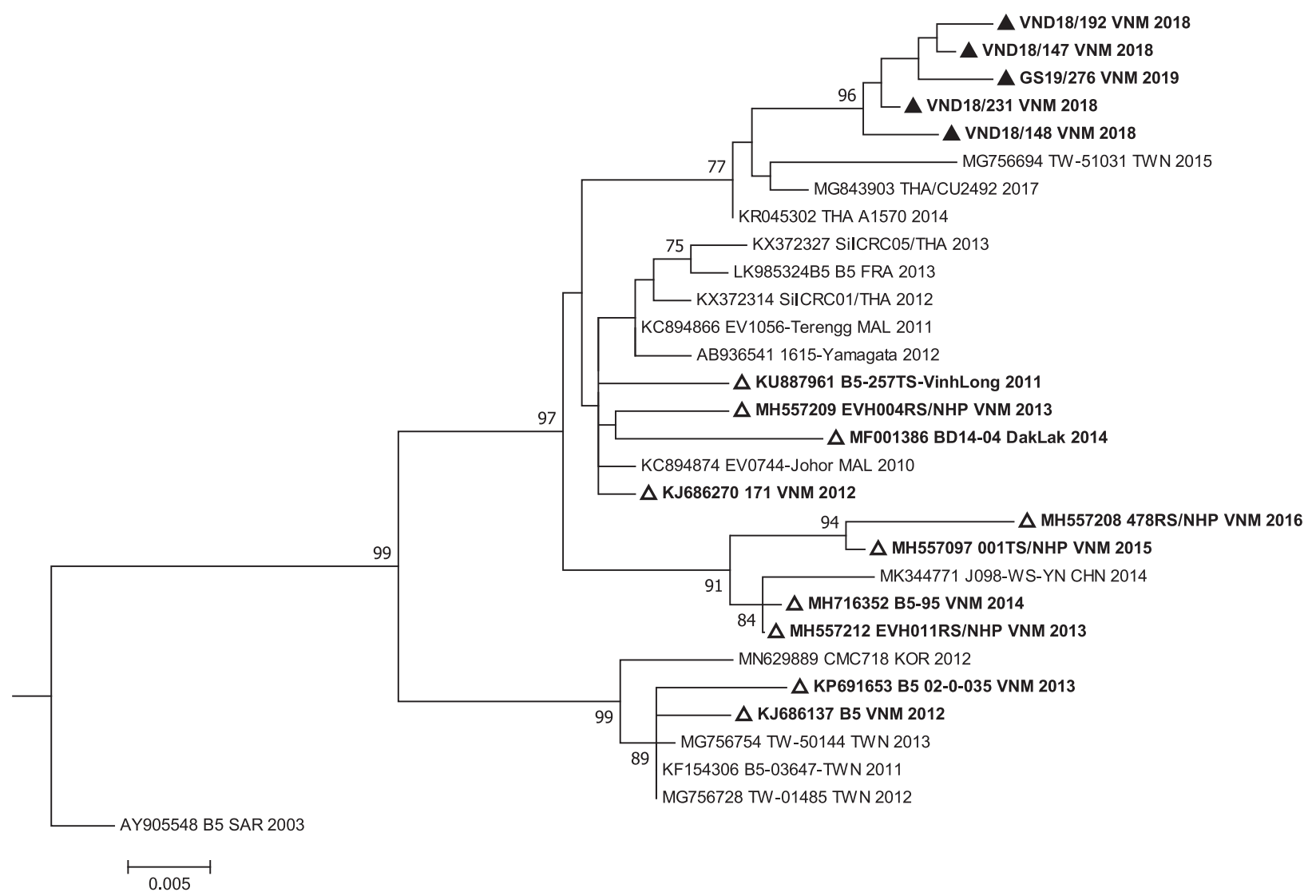

Figure 2. Phylogenic relationship between EV-A71 strains of genotype B5 identified in Vietnam

Note: $\Delta-$ Vietnamese strains described in this study, $\triangle-$ Vietnamese strains described in other studies. 
These viruses were most closely related to viruses identified in Thailand in 2017 [34] and they differed from the earlier detected Vietnamese strains EVA71 of genotype B5, which circulated in 2011-2016. The strains EV-A71 of genotype B5 were not detected in Russia.

\section{Discussion}

The results of the study showed that among enteroviruses isolated from patients with HFMD from South Vietnam, viruses EV-A71 prevailed. The EV-A71 strains accounted for $68 \%$ of all identified viruses. Viruses CV-A10 amounted to $23 \%$ of all isolated viruses and $9 \%$ were viruses of three types - CV-A16, CV-A6 and CV-A2. The prevalence of EV-A71 viruses in the examined patients determined the fact that in $90 \%$ of children the disease was moderate or severe and it proceeded with various complications. The majority of cases occurred in three provinces of South Vietnam from the 12 provinces included in the study. It is important to note that $40.7 \%$ of cases were reported in the Dong Thap Province, located in the southwestern part of South Vietnam on the border with the Kingdom of Cambodia. This province, together with the neighboring province of An Giang, constituted a single epidemiological focus. In the province of Ben Tre, which is located in the southeast of the country, $20.3 \%$ of the investigated cases of enterovirus infection were detected. All in all in three provinces Dong Thap, An Giang and Ben Tre, located in southern Vietnam in the Mekong Delta, $78 \%$ of cases were revealed in our study. According to molecular studies $90 \%$ of identified EV-A71 strains were attributed to genotype C4. These data allowed us to confirm the resumption of the activity of EV-A71 virus of genotype C4. Phylogenic analysis showed that the studied strains EV-A71 of genotype $\mathrm{C} 4$ entered the same cluster, and most of them were very close to the strains EV-A71 of genotype C4 from the Chinese province of Yunnan. These strains differed from EV-A71 strains of genotype C4, which were identified in Russia in 2013-2014, as well as from the strains of the same genotype circulating in Vietnam in 2003-2005 and 2011-2012. The EVA71 strains of genotype B5 from this study were related to the strains of the same genotype identified in Thailand, but differed from similar strains circulating in Vietnam from 20011 to 2016. It should be especially noted that enteroviruses EV-A71 of genotype B5 have not yet been detected in Russia.

The results of performed phylogenic analysis of enterovirus strains indicate the influence of the Mekong as the largest Asian waterway, the basin of which is densely populated, on the formation of unique epidemic focus of enterovirus infection. A very close relationship between the majority of studied Vietnamese EV-A71 strains of genotype
$\mathrm{C} 4$ and the viruses circulated in the Chinese province of Yunnan was established in our study. The EV-A71 strains of genotype B5 were genetically close to the strains from Thailand, through which the Mekong also flows.

Previously, in our research performed in collaboration with Vietnamese colleagues [6] we identified and characterized 20 strains of CV-A10. It is important to note that these CV-A10 strains were most closely related to the viruses from the Yunnan Province, as well as most of the EV-A71 strains of genotype C4. The Yunnan Province is located in the upper Mekong.

We revealed the strain VND18/227 which genetically differed from other EV-A71 strains of genotype $\mathrm{C} 4$ in our research. These differences prove that the case of infection caused by this virus was not epidemiologically associated with the majority of analyzed cases of HFMD caused by viruses of the same genotype. The fact that some other strains isolated in different regions of the world entered the genetic cluster together with the strain VND18/227 indicates that the genetic variant of genotype $\mathrm{C} 4$ of EV-A71 virus, represented by all these strains, was widespread in the world in 2017-2019. The virus of this genetic variant could have been introduced into the Mekong Delta both by tourists from abroad and as a result of internal migration of the population from the North or Central Vietnam to the South Vietnam.

The results our molecular study showed that $90 \%$ of identified EV-A71 strains of genotype C4 differed genetically from the EV-A71 strains of the same genotype which earlier circulated in Vietnam. These data allowed us to confirm the resumption of wide circulation of EV-A71 virus of genotype C4 in South Vietnam. This new peak of circulation can be very likely explained by the introduction of new variants of this virus into Vietnamese provinces located in the Mekong Delta.

A number of publications [23, 24, 25, 31] provide the results of some long-term studies of patients who suffered from HFMD and their contact persons who lived in the southern provinces of Vietnam. The authors proved the role of EV-A71 virus as the main etiological factor of HFMD, which was the emerging infection with the highest incidence in Vietnam over many years (2013-2018). Simultaneously with the EV-A71 virus, other representatives of Enterovirus A species such as CV-A10, CV-A6 and CV-A16 circulated in these provinces. In 2018, co-circulation in Vietnam of EV-A71 viruses belonged to two genotypes C4 and B5 was described; these data coordinate with our research. Viruses of both genotypes were mainly detected during outbreaks of enterovirus infection registered in the same period of time in China and Taiwan. An article published in 2019 [24] provides data from a survey of 150 children under 15 years of age with HFMD and 600 
of their contact persons in Dong Thap Province located in the Mekong Delta. The average age of the patients was 18 months. The diagnosis was laboratory confirmed in 113 patients and 142 contacts. Enteroviruses EV-A71, CVA6 and CVA16 were identified in patients and in contact persons. All the data given in the publications of the Vietnamese colleagues correspond well with the results of our research.

The peak of HFMD incidence in Vietnam was recorded in 2011; the largest number of cases was registered in the southern provinces. In 2011, the Ministry of Health of Vietnam classified HFMD as a severe infectious disease (infectious disease of class B) with a high epidemic potential and included it in the list of infectious diseases for weekly reporting [37]. The surveillance system for enterovirus infection was created in the South Vietnam in 2012. This system is based on monitoring the incidence of HFMD (ICD code No. 10 - B08.4), it includes obligatory laboratory confirmation of severe and fatal cases of enterovirus infection and identification of isolated enterovirus strains [36]. The highest incidence of enterovirus infection and the highest number of deaths were associated with enterovirus EV-A71. Circulation of EV-A71 genotypes C1, C4, C5, and B5 was recorded at different periods of time in Vietnam. The analysis of the phylogenetic relationships of the Vietnamese strains of viruses EV-A71 showed multiple importations of this virus from neighboring territories and a wide spread within the country, which led to maintaining the incidence of HFMD at a high level up to now.

In Russia the epidemic process and the structure of clinical forms of enterovirus infection changed in different periods and on different territories of the country. Previously, in certain regions of the country, enterovirus infection was mostly characterized as enterovirus meningitis, which is separately registered in the state statistical report of the Russian Federation for infectious diseases [1, 9, 13, $14,17]$. In recent years, the clinical forms of enterovirus infection with exanthema as HFMD have begun to prevail in many regions of the country [2, $3,7,15,16]$. The proportion of severe and moderate forms of infection, represented by enterovirus meningitis, has decreased and there is a tendency to shift the clinical picture towards a milder disease. HFMD is more common in unorganized children aged less than three years, as well as in children of 3-6 years old attending nursery schools. It is obvious that among young children, the transmission of infection by direct contact is realized very rapidly, which leads to the emergence of group cases and outbreaks of the infection. Enterovirus meningitis is more often observed among children aged 3-6 and 7-14 years. Group cases of enterovirus meningitis are usually registered in preschool institutions and schools.
Changes in the structure of clinical forms of infection conformed to the process of changes in the enterovirus types prevailing in the circulation among the population. In previous years in the North-West of Russia, epidemic rises of enterovirus infection were associated with the active circulation of enteroviruses belonging to the species B of enteroviruses, which caused enterovirus meningitis. Etiological agents of enterovirus meningitis were often ECHO30 viruses, as well as ECHO6, ECHO9 and Coxsackieviruses $\mathrm{B}$ of different types [1, 7, 9, $13,14,17]$. During the last years enterovirus infection with exanthema provoked by Coxsackieviruses of species A, including virus EV-A71 has been the leading clinical form of enterovirus infection in many regions of Russia.

From 2017 Enteroviruses species A constituted half of enteroviruses detected in patients with enterovirus infection. Different types of Enteroviruses species A dominated in the circulation in different years. In the second decade of the $21^{\text {st }}$ century, group cases of HFMD were recorded for the first time on some North-Western territories of Russia. Preschool children were mostly involved in the epidemic process. On all these territories, the etiological factor of infection was established as Coxsackievirus A16 [2]. Later Coxsackievirus A6 occupied the leading position among enteroviruses that caused enterovirus infection with exanthema in Russia. In 2017, the circulation of this virus was fixed on 64 territories of Russia, and on some territories it was the cause of outbreaks. From 2017 to 2019, sporadic cases of enterovirus exanthema among children of 1-2 years of age were often observed in Russia [16]. On some territories, group cases of enterovirus exanthema were registered among children 3-6 years old in preschool institutions. The infection was transmitted by contact; the disease usually proceeded in a mild form. The etiological agents of enterovirus infection were EV-A71 and Coxsackieviruses A6, and A16.

In general, the epidemic process and the etiology of enterovirus infection in Russia and in Vietnam have common features. At the same time the epidemic situation in these countries has some differences. The incidence of enterovirus infection can be influenced by geographic, climatic, economic, demographic and socio-hygienic factors, which are not the same in Russia and in Vietnam.

In the majority of territories of Russia the climate is temperate or cold with sharp fluctuations from minus to plus temperatures during the year, so seasonal rises in the incidence of enterovirus infection in the country, as a rule, occur in summer $[1,2$, $8,15,16]$. In summer, the temperature rises significantly all over Russia and people go for the vacations, mainly to the southern parts of the country. During the holidays, social contacts and physical activity expand; people go in for outdoor sports and swim 
in open reservoirs. On the contrary, in the southern provinces of Vietnam the temperature and humidity remain at a high level all the year round, respectively, the HFMD cases and outbreaks are registered throughout all the year and the annual number of the cases of enterovirus infection exceeds the total number of such cases in Russia. The high population density in Vietnam, which exceeds the population density of Russia many fold, and a high proportion of children also determine the higher incidence of enterovirus infection in Vietnam compared to Russia. The overcrowding of the population, the prolonged stay of children in the street, combined with a hot climate; support the active circulation of enteroviruses among the population in the southern provinces of Vietnam. The fact that more than $20 \%$ of Vietnamese population lives in the Mekong Delta show a significant impact of this river on the epidemic process of enterovirus infection in South Vietnam. The Mekong is the largest river in Indochina, which flows through China, Laos, Thailand, Cambodia and Vietnam. The Mekong River carries huge streams of water, including rainwaters and sewages, from all of these countries into the southern provinces of Vietnam, where it flows into the South China Sea. All these factors complicate the epidemic process of enterovirus infection in southern provinces of Vietnam, where the highest incidence of HFMD in the country is fixed.

\section{Conclusion}

The results of this research confirm the importance of the epidemiological study of different cases of enterovirus infection: sporadic, group and outbreaks as well as the need for virological and molecular investigations of patients' samples in order to establish the etiological factor of each case of the disease. The obtained results also provide new information on the circulation of non-poliomyelitis enteroviruses among the population of Russia and Vietnam - two countries, situated in different parts of the world. The results of the study give the possibility to trace the changes in the dominant types of enteroviruses circulating in two countries and help to understand the patterns of the evolution of the epidemic process of enterovirus infection in different periods. The obtained data once again emphasize that the surveillance of all clinical forms of enterovirus infection is indispensable for the Russian Federation and the Socialist Republic of Vietnam. The active epidemiological and virological surveillance plays the key role in informing the public health authorities about the changes in the epidemic situation concerning enterovirus infection in order to take appropriate measures and develop the adequate prevention strategies. The main goal of complex anti-epidemic and preventive measures is to reduce the incidence of enterovirus infection and the economic and social burden of this infection for both countries - Russia and Vietnam.

\section{References}

1. Бичурина М.А., Романенкова Н.И., Голицына Л.Н., Розаева Н.Р., Канаева О.И., Фомина С.Г., Крайнова Т.И., Шишко Л.А., Гордиенко Т.А., Пьяных В.А., Иванова Т.Г., Смелков С.Н., Лесникова М.В., Новикова Н.А. Роль энтеровируса ЕСНО30 в этиологии энтеровирусной инфекции на Северо-Западе России в 2013 году // Журнал инфектологии. 2014. T. 6, № 3. C. 84-91. [Bichurina M.A., Romanenkova N.I., Golitsyna L.N., Rozaeva N.R., Kanaeva O.I., Fomina S.G., Krainova T.I., Shishko L.A., Gordienko T.A., Pianykh V.A., Ivanova T.G., Smelkov S.N., Lesnikova M.V., Novikova N.A. Role of Enterovirus ECHO 30 as the etiological agent of enterovirus infection in the North-West of Russia in 2013. Zhurnal infektologii = Journal Infectology, 2014, vol. 6, no. 3, pp. 84-91. (In Russ.)] doi: 10.22625/2072-6732-2014-6-3-84-91

2. Бичурина М.А., Романенкова Н.И., Новикова Н.А., Голицына Л.Н., Розаева Н.Р., Канаева О.И., Ермакова М.В., Камынина Л.С., Мадоян А.Г., Валдайцева Н.В., Леонова Н.П., Иванова Т.Г. Групповые заболевания энтеровирусной инфекцией, обусловленные вирусами Коксаки А16, на Северо-Западе России // Журнал микробиологии, эпидемиологии и иммунобиологии. 2014. № 2. С. 51-58. [Bichurina M.A., Romanenkova N.I., Novikova N.A., Golitsyna L.N., Rozaeva N.R., Kanaeva O.I., Ermakova M.V., Kamynina L.S., Madoyan A.G., Valdaitseva N.V., Leonova N.P., Ivanova T.G. Group enterovirus infection due to Coxsackievirus A16 in Northwestern Russia. Zhurnal mikrobiologii, epidemiologii $i$ immunobiologii $=$ Journal of Microbiology, Epidemiology and Immunobiology, 2014, vol. 2, pp. 51-58. (In Russ.)]

3. Голицына Л.Н., Зверев В.В., Парфенова Н.В., Епифанова Н.В., Сашина Т.А., Кашников А.Ю., Григорьева Г.И., Новикова Н.А. Вирус Коксаки А6 в Российской Федерации в 2014 году // Дальневосточный журнал инфекционной патологии. 2015. № 28. C. 12-20. [Golitsyna L.N., Zverev V.V., Parfenova O.V., Epifanova N.V., Sashina T.A., Kashnikov A.Y., Grigor'eva G.I., Novikova N.A. Coxsackievirus A6 in Russian Federation in 2014. Dal'nevostochny zhurnal infektsionnoy patologii = The Far Eastern Journal of Infectious Pathology, 2015, no. 285, pp. 12-20. (In Russ.)]

4. Глицына Л.Н., Зверев В.В., Парфенова О.В., Новикова Н.А. Эпидемические варианты неполиомиелитных энтеровирусов в России // Медицинский альманах. 2015. Т. 40, № 5. С. 136-140. [Golitsyna L.N., Zverev V.V., Parfenova O.V., Novikova N.A. Epidemic variants of non-poliomyelitic enteroviruses in Russia. Medical Almanac, 2015, vol. 40, no. 5, pp. 136-140. (In Russ.)]

5. Голицына Л.Н., Зверев В.В., Пономарева Н.В., Кашников А.Ю., Леонов А.В., Сашина Т.А., Епифанова Н.В., Резайкин А.В., Сапега Е.Ю., Новикова Н.А. Эпидемиологическая ситуация по энтеровирусной инфекции в РФ в 2019 году: заболеваемость, результаты лабораторной диагностики, прогноз на 2020 г. // Заболеваемость, этиологическая структура и вопросы профилактики энтеровирусной (неполио) инфекции. 2020. № 7. С. 5-12. [Golitsyna L.N., Zverev V.V., Ponomareva N.V., Kashnikov A.Yu., Leonov A.V., Sashina T.A., Epifanova N.V., Rezaikin A.V., Sapega E.Yu., Novikova N.A. Epidemiological situation concerning enterovirus infection in the Russian Federation in 2019: incidence, laboratory diagnostics, prognosis for 2020. Zabolevaemost', etiologicheskaya struktura i voprosy profilaktiki enterovirusnoy (nepolio) infektsii = Incidence, Etiological Structure and Prevention of Enterovirus Infection, 2020, no. 7, pp. 5-12. (In Russ.)] 
6. Голицына Л.Н., Зверев В.В., Пономарева Н.В., Романенкова Н.И., Нгуен Т.Т.Т., Канаева О.И., Селиванова С.Г., Леонов А.В., Розаева Н.Р., Кашников А.Ю., Бичурина М.А., Новикова Н.А. Молекулярно-эпидемиологический мониторинг циркуляции вируса Коксаки А10 // Здоровье населения и среда обитания. 2021. № 4. С. 43-49. [Golitsyna L.N., Zverev V.V., Ponomareva N.V., Romanenkova N.I., Nguyen T.T.T., Kanaeva O.I., Selivanova S.G., Leonov A.V., Rozaeva N.R., Kashnikov A.Yu., Bichurina M.A., Novikova N.A. Molecular epidemiological monitoring of circulation of Coxsackievirus A10. Zdorov'e naseleniya i sreda obitaniya = Public Health and Life Environment, 2021, no. 4, pp. 43-49. (In Russ.)] doi: 10.35627/2219-5238/2021-337-4-43-49

7. Голицына Л.Н., Зверев В.В., Селиванова-Фомина С.Г., Пономарева Н.В., Кашников А.Ю., Созонов Д.В., Сашина Т.А., Епифанова Н.В., Евплова И.А., Резайкин А.В., Сапега Е.Ю., Новикова Н.А., Ефимов Е.И. Этиологическая структура энтеровирусных инфекций в Российской Федерации в 2017-2018 гг. // Здоровье населения и среда обитания. 2019. № 8. C. 30-38. [Golitsyna L.N., Zverev V.V., Selivanova S.G., Ponomareva N.V., Kashnikov A.Yu., Sozonov D.V., Sashina T.A., Epifanova N.V., Evplova I.A., Rezaykin A.V., Sapega E.Yu., Novikova N.A., Efimov E.I. Etiological structure of enterovirus infection in the Russian Federation in 2017-2018. Zdorov'e naseleniya $i$ sreda obitaniya $=$ Public Health and Life Environment, 2019, no. 8, pp. 30-38. (In Russ.)] doi: 10.35627/2219-5238/2019-317-8-30-38

8. Лукашев А.Н., Иванова О.Е., Худякова Л.В. Социально-экономическая значимость энтеровирусной инфекции и ее роль в структуре инфекционной патологии в мире // Журнал микробиологии. 2010. № 5. С. 113-120. [Lukashev A.N., Ivanova O.E., Khudyakova L.V. Socio-economic significance of enterovirus infection and its role in the structure of infectious pathology in the world. Zhurnal mikrobiologii, epidemiologii $i$ immunobiologii $=$ Journal of Microbiology, Epidemiology and Immunobiology, 2010, vol. 5, pp. 113-120. (In Russ.)]

9. Лукашев А.Н., Резник В.И., Иванова О.Е., Еремеева Т.П., Каравянская Т.Н., Перескокова М.А., Лебедева Л.А., Пашкевич В.А., Михайлов М.И. Молекулярная эпидемиология вируса ЕСНО 6 - возбудителя вспышки серозного менингита в Хабаровске в 2006 г. // Вопросы вирусологии. 2008. T. 53, № 1. С. 16-21. [Lukashev A.N., Reznik V.I., Ivanova O.E., Eremeyeva T.P., Karavyanskaya T.N., Pereskokova M.A., Lebedeva L.A., Lashkevich V.A., Mikhallov M.I. Molecular epidemiology of ECHO 6 virus, the causative agent of the 2006 outbreak of serous meningitis in Khabarovsk. Voprosy virusologii $=$ Problems of Virology, 2008, vol. 53, no. 1, pp. 16-21. (In Russ.)]

10. О состоянии санитарно-эпидемиологического благополучия населения в Российской Федерации в 2018 году: государственный доклад. М.: Федеральная служба по надзору в сфере защиты прав потребителей и благополучия человека, 2019. 254 c. [State of sanitary and epidemiological wellbeing of the population in the Russian Federation in 2018: state report. Moscow: Russian Federal Service for Surveillance on Consumer Rights Protection and Human Wellbeing, 2019. 254 p. (In Russ.)]

11. О состоянии санитарно-эпидемиологического благополучия населения в Российской Федерации в 2019 году: Государственный доклад. М.: Федеральная служба по надзору в сфере защиты прав потребителей и благополучия человека, 2020. 299 c. [State of sanitary and epidemiological wellbeing of the population in the Russian Federation in 2019: state report. Moscow: Russian Federal Service for Surveillance on Consumer Rights Protection and Human Wellbeing, 2020.299 p. (In Russ.)]

12. Патент № 2743352 Российская Федерация, МПК С12N 15/00 (2006.01). Способ дифференциальной амплификации фрагмента области VP1 генома энтеровирусов видов Enterovirus А и Enterovirus B: № 2020117726; заявлено 2020.05.19: опубликовано 2021.02.17 / Голицына Л.Н. Патентообладатель: ФБУН Нижегородский НИИ эпидемиологии и микробиологии им. академика И.Н. Блохиной. 14 с. [Patent No. 2743352 Russian Federation, Int. Cl. C12N 15/00 (2006.01). Method for differential amplification of VP1 region fragment of enterovirus genome enterovirus A and enterovirus B. No. 2020117726; application: 2020.05.19: date of publication 2021.02.17 / Golitsyna L.N. Proprietors: Federalnoe byudzhetnoe uchrezhdenie nauki "Nizhegorodskij nauchno-issledovatelskij institut epidemiologii i mikrobiologii im. akademika I.N. Blokhinoj". 14 p.]

13. Романенкова Н.И., Бичурина М.А., Голицына Л.Н., Розаева Н.Р., Канаева О.И., Черкасская И.В., Кириллова Л.П., Батаева А.Ю., Барышникова А.С., Новикова Н.А. Неполиомиелитные энтеровирусы, обусловившие подъем заболеваемости энтеровирусной инфекцией на ряде территорий России в 2016 году // Журнал инфектологии. 2017. T. 9, № 3. C. 98-108. [Romanenkova N.I., Bichurina M.A., Golitsyna L.N., Rozaeva N.R., Kanaeva O.I., Cherkasskaya I.V., Kirillova L.P., Bataeva A.Yu., Baryshnikova A.S., Novikova N.A. Nonpolio enteroviruses which caused the rise of enterovirus infection on some territories of Russia in 2016. Zhurnal infektologii = Journal Infectology, 2017, vol. 9, no. 3, pp. 98-108. (In Russ.)] doi: 10.22625/2072-6732-2017-9-3-98-108

14. Романенкова Н.И., Бичурина М.А., Розаева Н.Р., Канаева О.И., Шишко Л.А., Черкасская И.В., Кириллова Л.П. Вирусы Коксаки В1-6 как этиологический фактор энтеровирусной инфекции // Журнал инфектологии. 2016. Т. 8, № 2. C. 65-71. [Romanenkova N.I., Bichurina M.A., Rozaeva N.R., Kanaeva O.I., Shishko L.A., Cherkasskaya I.V., Kirillova L.P. Coxsackieviruses B1-6 as etiological factor of enterovirus infection. Zhurnal infektologii = Journal Infectology, 2016, vol. 8, no. 2, pp. 65-71. (In Russ.)]

15. Романенкова Н.И., Голицына Л.Н., Бичурина М.А., Розаева Н.Р., Канаева О.И., Зверев В.В., Созонов Д.В., Черкасская И.В., Кириллова Л.П., Ермакова М.В., Камынина Л.С., Петухова М.Б., Грицай А.Б., Новикова Н.А. Заболеваемость энтеровирусной инфекцией и особенности циркуляции неполиомиелитных энтеровирусов на некоторых территориях России в 2017 году // Журнал инфектологии. 2018. T. 10, № 4. C. 124-133. [Romanenkova N.I., Golitsyna L.N., Bichurina M.A., Rozaeva N.R., Kanaeva O.I., Zverev V.V., Sozonov D.V., Cherkasskaya I.V., Kirillova L.P., Ermakova M.V., Kamynina L.S., Petukhova M.B., Gritsay A.B., Novikova N.A. Enterovirus infection morbidity and peculiarities of nonpolio enteroviruses circulation on some territories of Russia in 2017. Zhurnal infektologii = Journal Infectology, 2018, vol. 10, no. 4, pp. 124-133. (In Russ.)] doi: 10.22625/2072-6732-2018-10-4-124-133

16. Романенкова Н.И., Розаева Н.Р., Бичурина М.А., Канаева О.И., Чхинджерия И.Г., Шишкина Л.В., Мадоян А.Г., Валдайцева Н.В. Эпидемиологические аспекты энтеровирусной инфекции в Российской Федерации за период 2018-2019 гг. // Журнал инфектологии. 2021. Т. 13, № 1. C. 108-116. [Romanenkova N.I., Rozaeva N.R., Bichurina M.A., 
Kanaeva O.I., Chkhyndzheriya I.G., Shishkina L.V., Madoyan A.G., Valdaitseva N.V. Epidemiological aspects of enterovirus infection in the Russian Federation during the period of 2018-2019. Zhurnal infektologii = Journal Infectology, 2021, vol. 13, no. 1, pp. 108-116. (In Russ.)] doi: 10.22625/2072-6732-2021-13-1-108-116

17. Шишко Л.А., Романенкова Н.И., Бичурина М.А., Гордиенко Т.А., Розаева Н.Р., Голицына Л.Н., Фомина С.Г., Канаева О.И., Лялина Л.В., Новикова Н.А. Этиология сезонных подъемов заболеваемости энтеровирусной инфекцией в Архангельской области // Инфекция и иммунитет. 2013. Т. 3, № 1. C. 65-72. [Shishko L.A., Romanenkova N.I., Bichurina M.A., Gordienko T.A., Rozaeva N.R., Golitcina L.N., Fomina L.B., Kanaeva O.I., Lialina L.V., Novikova N.A. Etiology of seasonal increasing of enteroviral infection in Arkhangelsk oblast. Infektsiya i immunitet $=$ Russian Journal of Infection and Immunity, 2013, vol. 3, no. 1, pp. 65-72. (In Russ.)] doi: 10.15789/2220-7619-2013-1-65-72

18. Akhmadishina L.V., Govorukhina M.V., Kovalev E.V., Nenadskaya S.A., Ivanova O.E., Lukashev A.N. Enterovirus A71 meningoencephalitis outbreak, Rostov-on-Don, Russia, 2013. Emerg. Infect. Dis., 2015, vol. 21, no. 8, pp. 1440-1443. doi: 10.3201/ eid2108.141084

19. Bian L., Wang Y., Yao X., Mao Q., Xu M., Liang Z. Coxsackitvirus A6: a new emerging pathogen causing hand, foot and mouth disease outbreaks worldwide. Expert Rev. Anti-infect. Ther., 2015, vol. 13, no. 9, pp. 1061-1071. doi: 10.1586/14787210.2015.1058156

20. Böttcher S., Diedrich S., Keeren K., the Laboratory Network for Enterovirus Diagnostic (LaNED). Increased detection of enterovirus A71 infections, Germany, 2019. Euro Surveill., 2019, vol. 24, no. 39: 1900556. doi: 10.2807/1560-7917.ES.2019.24.39.1900556

21. Chu S.T., Kobayashi K., Bi X., Ishizaki A., Tran T.T., Phung T.T.B., Pham C.T.T., Nguyen L.V., Ta T.A., Khu D.T.K., Agoh M., Pham A.N., Koike S., Ichimura H. Newly emerged enterovirus-A71 C4 sublineage may be more virulent than B5 in the 2015-2016 hand-foot-and-mouth disease outbreak in northern Vietnam. Sci. Rep., 2020, vol. 10: 159. doi: 10.1038/s41598-019-56703-5

22. Donato C., Le T.H., Nguen T.H., Tran M.H., Le V.D., Ta T.D.N., Nguen V.K., Nguen V.T., Vijaykrishna D. Genetic characterization of Enterovirus 71 strains circulating in Vietnam in 2012. Virology, 2016, vol. 495, pp. 1-9. doi: 10.1016/j.virol.2016.04.026

23. Hoang C.Q., Nguyen H.D., Ho N.X., Vu T.H.T., Pham T.T.M., Nguyen K.T., Nguyen H.T., Hoang L.T., Clapham H., Nguyen T.T.T., Phan L.T. Incidence of infection of Enterovirus 71 and Coxsackieviruses A6 and A16 among household contacts of index cases in Dong Thap Province, Southern Vietnam. BioMed Res. Int., 2020: 9850351. doi: 10.1155/2020/9850351

24. Hoang C.Q., Nguyen T.T.T., Ho N.X., Nguyen H.D., Nguyen A.B., Nguyen T.H.T., Phan H.C., Phan L.T. Transmission and serotype features of hand foot mouth disease in household contacts in Dong Thap, Vietnam. BMC Infect. Dis., 2019, vol. 19: 933. doi: 10.1186/s12879-019-4583-1

25. Hoang M.T.V., Nguyen T.A., Tran T.T., Vu T.T.H., Le N.T.N., Nguyen T.H.N., Le T.H.N., Nguyen T.T.H., Nguyen T.H., Le N.T.N., Truong H.K., Du T.Q., Ha M.T., Ho L.V., Do C.V., Nguyen T.N., Nguyen T.M.T., Sabanathan S., Phan T.Q., Nguyen Van V.C., Thwaites G.E., Wills B., Thwaites C.L., Le V.T., van Doorn H.R. Clinical and aetiological study of hand, foot and mouth disease in southern Vietnam, 2013-2015: inpatients and outpatients. Int. J. Infect. Dis., 2019, vol. 80, pp. 1-9. doi: 10.1016/ j.ijid.2018.12.004

26. Kumar S., Stecher G., Tamura K. MEGA7: Molecular Evolutionary Genetics Analysis version 7.0 for bigger datasets. Mol. Biol. Evol., 2016, vol. 33, no. 7, pp. 1870-1874. doi: 10.1093/molbev/msw054

27. Le T.V., Nguyen V.T.T., Nguyen Q.H., Pham D.T. Molecular epidemiology analysis of enterovirus 71 strains isolated in Dak Lak, Vietnam, 2011-2016. J. Med. Virol., 2019, vol. 91. pp. 56-64. doi: 10.1002/jmv.25286

28. Mirand A., Henqell C., Archimbaud C., Ughetto S., Antona D., Bailly J.L., Peigue-Lafeuille H. Outbreak of hand, foot and mouth disease/herpangina associated with coxsackievirus A6 and A10 infections in 2010, France: a large citywide, prospective observational study. Clin. Microbiol. Infect., 2012, vol. 18, no. 5, pp. 110-118. doi: 10.1111/j.1469-0691.2012.03789.x

29. Nguen T.T.T., Donato C., Trang V.T.H., Kien N.T., Trang P.M.M.T., Khanh T.Q., Nguyet D.T., Sessions O.M., Cuong H.Q., Lan P.T., Huong V.T.Q., van Doorn H.R., Vijaykrishna D. Evolution and spatiotemporal dynamics of enterovirus A71 subgenogroups in Vietnam. J. Infect. Dis., 2017, vol. 216, no. 11, pp. 1371-1379. doi: 10.1093/infdis/jix500

30. Nguyen N.T., Pham H.V., Hoang C.Q., Nguyen T.M., Nguyen L.T., Phan H.C., Phan L.T., Vu L.N., Tran Minh N.N. Epidemiological and clinical characteristics of children who died from hand, foot and mouth disease in Vietnam, 2011. BMC Infect Dis., 2014, vol. 14: 341. doi: 10.1186/1471-2334-14-341

31. Nhan L.N.T., Khanh T.H., Hong N.T.T., Van H.M.T., Nhu L.N.T., Ny N.T.H., Nguyet L.A., Thanh T.T., Anh N.T., Hang V.T.T., Qui P.T., Viet H.L., Tung T.H., Ha D.Q., Tuan H.M., Thwaites G., Chau N.V.V., Thwaites L., Hung N.T., van Doorn H.R., Tan L.V. Clinical, etiological and epidemiological investigations of hand, foot and mouth disease in southern Vietnam during 2015-2018. PLoS Negl. Trop. Dis., 2020, vol. 14, no. 8: e0008544. doi: 10.1371/journal. pntd.0008544

32. Nix W.A., Oberste M.S., Pallansch M.A. Sensitive seminested PCR amplification of VP1 sequences for direct identification of all enterovirus serotypes from original clinical specimens. Clin. Microbiol., 2006, vol. 44, no. 8, pp. 2698-2704. doi: 10.1128/ JCM.00542-06

33. Österback R., Vuorinen T., Linna M., Susi P., Hyypiä T., Waris M. Coxsackievirus A6 and hand, foot, and mouth disease, Finland. Emerg. Infect. Dis., 2009, vol. 15, no. 9, pp. 1485-1488. doi: 10.3201/eid1509.090438

34. Puenpa J., Auphimai C., Korkong S., Vongpunsawad S., Poovorawan Y. Enterovirus A71 infection, Thailand, 2017. Emerg. Infect. Dis., 2018, vol. 24, no. 7, pp. 1386-1387. doi: 10.3201/eid2407.171923

35. Sun H., Gao M., Cui D. Molecular characteristics of the VP1 region of enterovirus 71 strains in China. Gut Pathog., 2020, vol. 14, no. 12: 38. doi: 10.1186/s13099-020-00377-2

36. Tan le V., Thai le H., Phu N.H., Nghia H.D., Chuong L.V., Sinh D.X., Phong N.D., Mai N.T., Man D.N., Hien V.M., Vinh N.T., Day J., Chau N.V., Hien T.T., Farrar J., de Jong M.D., Thwaites G., van Doorn H.R., Chau T.T. Viral aetiology of central nervous system infections in adults admitted to a tertiary referral hospital in southern Vietnam over 12 years. PLoS Negl. Trop. Dis., 2014, vol. 8, no. 8: e3127. doi: 10.1371/journal.pntd.0003127

37. Thoa le P.K., Chiang P.S., Khanh T.H., Luo S.T., Dan T.N., Wang Y.F., Thuong T.C., Chung W.Y., Hung N.T., Wang J.R., Nhan le N.T., Thinh le Q., Su I.J., Dung T.D., Lee M.S. Genetic and antigenic characterization of enterovirus 71 in Ho Chi Minh City, Vietnam, 2011. PLoS One, 2013, vol. 8, no. 7: e69895. doi: 10.1371/journal.pone.0069895 
38. WHO. A guide to clinical management and public health response for hand, foot and mouth disease (HFMD). WHO: Geneva, 2011. $71 p$.

39. WHO. List of Blueprint priority diseases. February 2018 - second annual review. WHO: Geneva, 2018. 17 p

40. WHO. Polio laboratory manual. $4^{\text {th }}$ edition. WHO: Geneva, 2004. 157 p.

41. Zhang Y., Wang D., Yan D., Zhu S., Liu J., Wang H., Zhao S., Yu D., Nan L., An J., Chen L., An H., Xu A., Xu W. Molecular evidence of persistent epidemic and evolution of subgenotype B1 coxsackievirus A16-associated hand, foot, and mouth disease in China. J. Clin. Microbiol., 2010, vol. 48, no. 2, pp. 619-622. doi: 10.1128/JCM.02338-09

\section{Авторы:}

Романенкова Н.И., к.М.Н., старший научный сотрудник, ведущий научный сотрудник лаборатории этиологии и контроля вирусных инфекций ФБУН НИИ эпидемиологии и микробиологии имени Пастера, Санкт-Петербург, Россия

Голицына Л.Н., к.б.н., ведущий научный сотрудник лаборатории молекулярной эпидемиологии вирусных инфекций ФБУН Нижегородский НИИ эпидемиологии и микробиологии им. академика И.Н. Блохиной, Нижний Новгород, Россия; Нгуен Т.T.т., д.н., зав. лабораторией энтеровирусов отдела иммунологии и микробиологии, Институт Пастера в Хошимине, г. Хошимин, Вьетнам;

Пономарева Н.В., к.б.н., научный сотрудник лаборатории молекулярной эпидемиологии вирусных инфекций ФБУН Нижегородский НИИ эпидемиологии и микробиологии им. академика И.Н. Блохиной, Нижний Новгород, Россия; Леонов А.В., младший научный сотрудник лаборатории молекулярной эпидемиологии вирусных инфекций ФБУН Нижегородский НИИ эпидемиологии и микробиологии им. академика И.Н. Блохиной, Нижний Новгород, Россия; Канаева О.И., научный сотрудник лаборатории этиологии и контроля вирусных инфекций ФБУН НИИ эпидемиологии и микробиологии имени Пастера, Санкт-Петербург, Россия; Зверев В.В., к.б.н., старший научный сотрудник лаборатории молекулярной эпидемиологии вирусных инфекций ФБУН Нижегородский НИИ эпидемиологии и микробиологии им. академика И.Н. Блохиной, Нижний Новгород, Россия; Селиванова С.Г., к.б.н., старший научный сотрудник лаборатории молекулярной эпидемиологии вирусных инфекций ФБУН Нижегородский НИИ эпидемиологии и микробиологии им. академика И.Н. Блохиной, Нижний Новгород, Россия;

Розаева Н.P., к.М.Н., старший научный сотрудник, старший научный сотрудник лаборатории этиологии и контроля вирусных инфекций ФБУН НИИ эпидемиологии и микробиологии имени Пастера, Санкт-Петербург, Россия;

Лыонг М.Т., к.Х.н., зав. лабораторией тропической биомедицины Российско-Вьетнамский тропический научноисследовательский и технологический центр, южное отделение, г. Хошимин, Вьетнам;

Бичурина М.А., Д.М.н., старший научный сотрудник, зав. лабораторией лаборатории этиологии и контроля вирусных инфекций ФБУН НИИ эпидемиологии и микробиологии имени Пастера, Санкт-Петербург, Россия;

Новикова Н.А., д.б.н., профессор, зав. лабораторией молекулярной эпидемиологии вирусных инфекций ФБУН Нижегородский НИИ эпидемиологии и микробиологии им. академика И.Н. Блохиной, Нижний Новгород, Россия.

\section{Authors:}

Romanenkova N.I., PhD (Medicine), Senior Researcher, Leading Researcher, Laboratory of Etiology and Control of Viral Infections, St. Petersburg Pasteur Institute, St. Petersburg, Russian Federation; Golitsyna L.N., PhD (Biology), Leading Researcher, Laboratory of Molecular Epidemiology of Viral Infections, Blokhina Scientific Research Institute of Epidemiology and Microbiology of Nizhny Novgorod, Nizhny Novgorod, Russian Federation;

Nguyen T.T.T., MD, Head of Enteroviruses Laboratory, Institut Pasteur in Ho Chi Minh City, Ho Chi Minh City, Vietnam; Ponomareva N.V., PhD (Biology), Researcher, Laboratory of Molecular Epidemiology of Viral Infections, Blokhina Scientific Research Institute of Epidemiology and Microbiology of Nizhny Novgorod, Nizhny Novgorod, Russian Federation; Leonov A.V., Junior Researcher, Laboratory of Molecular Epidemiology of Viral Infections, Blokhina Scientific Research Institute of Epidemiology and Microbiology of Nizhny Novgorod, Nizhny Novgorod, Russian Federation;

Kanaeva O.I., Researcher, Laboratory of Etiology and Control of Viral Infections, St. Petersburg Pasteur Institute, St. Petersburg, Russian Federation;

Zverev V.V., PhD (Biology), Senior Researcher, Laboratory of Molecular Epidemiology of Viral Infections, Blokhina Scientific Research Institute of Epidemiology and Microbiology of Nizhny Novgorod, Nizhny Novgorod, Russian Federation;

Selivanova S.G., PhD (Biology), Senior Researcher, Laboratory of Molecular Epidemiology of Viral Infections, Blokhina Scientific Research Institute of Epidemiology and Microbiology of Nizhny Novgorod, Nizhny Novgorod, Russian Federation;

Rozaeva N.R., PhD (Medicine), Senior Researcher, Laboratory of Etiology and Control of Viral Infections, St. Petersburg Pasteur Institute, St. Petersburg, Russian Federation;

Luong M.T., PhD (Chemistry), Head of Laboratory of Tropical Biomedicine, Russian-Vietnamese Tropical Research and Technology Center, South Branch, Ho Chi Minh City, Vietnam;

Bichurina M.A., PhD, MD (Medicine), Senior Researcher, Head of the Laboratory of Etiology and Control of Viral Infections, St. Petersburg Pasteur Institute, St. Petersburg, Russian Federation; Novikova N.A., PhD, MD (Biology), Professor, Head of the Laboratory of Molecular Epidemiology of Viral Infections Blokhina Scientific Research Institute of Epidemiology and Microbiology of Nizhny Novgorod, Nizhny Novgorod, Russian Federation. 